\title{
Kepraktisan dan keefeltifan LKPD berbasis problem based learning untuk melatihkan kemampuan literasi sains pada materi asam basa
}

\section{Practicality and effectiveness of student's worksheet based on problem based learning to practice scientific literacy skill in matter acid and base}

\author{
Maftukhatun Ni'mah ${ }^{1}$; Aprianto; Nurul Hidayati; Rusly Hidayah* \\ ${ }^{1}$ Jurusan Kimia, Fakultas Matematika dan Ilmu Pengetahuan Alam, Universitas Negeri Surabaya, Surabaya-Indonesia \\ *Korespondensi:12nimah@gmail.com; ruslyhidayah@unesa.ac.id
}

\begin{abstract}
Hasil studi komperatif PISA menunjukkan bahwa tingkat literasi sains Indonesia masih rendah. Dari hasil studi tersebut menyatakan bahwa Indonesia berada pada peringkat 64 dari 65 negara dengan skor literasi sains 382 pada kajian ilmu pengetahuan alam siswa. Diperlukan pengembangan LKPD untuk melatihkan kemampuan literasi sains. Tujuan dari penelitian ini adalah menghasilkan LKPD berbasis problem based learning untuk melatihkan kemampuan literasi sains yang praktis dan efektif. Metode yang digunakan dalam penelitian ini adalah Research and Development (R\&D). Hasil penelitian yang telah dilakukan menunjukkan bahwa LKPD yang dikembangkan praktis dan efektif. Kepraktisan LKPD dilihat dari respon peserta didik mendapatkan tanggapan yang baik sebesar $94,99 \%$ dengan kategori amat baik. Keefektifan LKPD yang dikembangkan dilihat dari gain score dari hasi pre test dan post test peserta didik.
\end{abstract}

Kata kunci: LKPD, praktis, efektif

\begin{abstract}
The results of PISA's comperative studies show that the level of Indonesian science literacy is still low. From the results of the study stated that Indonesia is ranked 64 of 65 countries with a score of 382 science literacy on the study of natural science students. Necessary development of student's worksheet to trace the ability of science literacy. The purpose of this research is to produce student's worksheet based on problem based learning to trace the ability of science literacy which is practical and effective. The method used in this research is Research and Development (R\&D). The results of the research have shown that student's worksheet developed practical and effective. Student's worksheet practicality seen from student response get good response equal to $94,99 \%$ with very good category. The effectiveness of student's worksheet developed is seen from the gain score of the pre test and post test of the student.
\end{abstract}

Key words: Student's worksheet, practice, effective

DOI: https://doi.org/10.24114/jpkim.v9i3.8537

Konsep berpikir dalam dunia pendidikan dituntut untuk berubah oleh perkembangan global. Konsep berpikir telah berubah menjadi berpusat kepada siswa setelah sebelumya berpusat terhadap guru (Suyono \& Haryanto, 2011). Permendikbud No.81A tentang Implementasi Kurikulum 2013 menyatakan bahwa dalam kurikulum 2013 pembelajaran berpusat pada siswa.

Kegiatan inkuiri dan pendekatan ilmiah (scientific approach) dalam kurikulum 2013 secara umum mengarahkan siswa untuk mengembangkan literasi sains (Anjarsari, 2014). Menurut PISA (2006), literasi sains adalah kemampuan untuk mengidentifikasi isu ilmah, menjelaskan fenomena secara ilmiah dan menggunakan bukti ilmiah itu dalam kehidupan sehari-hari.

Indonesia merupakan salah satu peserta PISA di luar Negara industri maju yang tergabung dalam OECD (Maturradiyah \& Rusilowati, 2015). Tingkat literasi sains Indonesia masih rendah, Indonesia berada pada peringkat 64 dari 65 negara dengan skor literasi sains 382 pada kajian ilmu pengetahuan alam siswa. Sedangkan, ratarata skor dari semua Negara adalah 501 (PISA, 2006).

Perbedaan besar antara kurikulum dan proses pembelajaran yang dilaksanakan di sekolah- 
sekolah di Indonesia dengan tuntutan dalam PISA merupakan penyebab rendahnya literasi sains di Indonesia (Firman, 2007). Faktor-foktor yang diduga menjadi penyebab rendahnya literasi sains ini dipengaruhi oleh berbagai hal, seperti sistem pendidikan/kurikulum, metode pembelajaran, kompetensi guru, sarana dan fasilitas pembelajaran, sumber pembelajaran, bahan ajar, dan lain-lain.

Hasil studi lapangan yang telah dilakukan di SMAN 1 Sidayu dengan melakukan wawancara terhadap guru kimia dan pengisisan angket oleh peserta didik. Hasil wawancara terhadap salah satu guru kimia di SMAN 1 Sidayu menunjukkan bahwa di sekolah tersebut tidak menggunakan LKPD (Lembar Kerja Peserta Didik). Peserta didik hanya menggunakan buku siswa. Hal ini selaras dengan hasil angket respon peserta didik di SMAN 1 Sidayu yang menyatakan tidak menggunakan LKPD. Selain itu saat praktikum, peserta didik jarang diberikan fenomena dalam mengantarkan peserta didik untuk mempelajari kimia. Sehingga peserta didik belum terlatih untuk menghubungkan materi kimia dengan permasalahan yang ada dalam kehidupan sehari-hari.

Berdasarkan uraian tersebut perlu dilakukan pengembangan media pembelajaran untuk melatihkan kemampuan literasi sains. Media pembelajaran merupakan salah satu bagian penting untuk mencapai tujuan pendidikan dalam proses pembelajaran. Sebagai alat bantu mengajar yang turut mempengaruhi iklim, kondisi dan lingkungan belajar yang ditata dan diciptakan oleh guru merupakan salah satu fungsi utama media pembelajaran (Arsyad, 2014).

Salah satu media pembelajaran yang dapat membantu untuk melatihkan literasi sains adalah LKPD (Lembar Kerja Peserta Didik). Menurut Widjajanti (2008) LKPD (Lembar Kerja Peserta Didik) merupakan salah satu sumber belajar yang dapat dikembangkan oleh pendidik sebagai fasilitator dalam kegiatan pembelajaran. LKPD yang disusun dapat dirancang dan dikembangkan sesuai dengan kondisi dan situasi kegiatan.

Diperlukan model pembelajaran yang cocok untuk melatihkan literasi sains. Salah satu model pembelajaran yang mendukung untuk melatihkan literasi sains adalah pembelajaran berbasis masalah atau Problem Based Learning. Problem Based Learning adalah keseluruhan dari pembelajaran untuk memunculkan pemikiran penyelesaian masalah; dimulai dari awal pembelajaran disintesis dan diorganisasikan dalam situasi masalah (Toharudin dkk., 2011 ).

Ilmu kimia merupakan salah satu ilmu cabang dari sains. Ilmu kimia merupakan suatu cabang ilmu yang di dalamnya mempelajari bangun (struktur) materi dan perubahan-perubahan yang dialami materi ini dalam proses alamiah maupun dalam eksperimen yang direncanakan (Keenan, 1984). Ilmu kimia merupuakan salah satu ilmu yang dipelajari pada jenjang SMA/MA. Tujuan pengajaran kimia di SMA/MA adalah peserta didik dapat memahami konsep, prinsip, hukum, teori kimia serta saling keterkaitannya dan penerapannya untuk menyelesaikan masalah dalam kehidupan sehari-hari dan teknologi (BSNP, 2006).

Materi asam basa merupakan salah satu materi kimia yang diajarkan pada siswa SMA kelas XI. Salah satu sub materi dalam asam basa adalah indikator buatan dan idikator alami. Materi asam basa sangat dekat dengan kehidupan sehari-hari manusia. Sehingga siswa akan mudah dalam mempelajari fenomena-fenomena yang berkaitan dengan materi asam basa jika media yang digunakan mendukung hal tersebut. Media yang dimaksud adalah LKPD (Lembar Kerja Peserta Didik). Selain itu kemampuan literasi sains dapat dimasukkan dalam media tersebut, sehingga dengan media ini dapat melatihkan literasi sains siswa.

\section{Metode}

Penelitian ini telah dilakukan uji coba di SMA Negeri 1 Sidayu pada semester ganjil tahun ajaran 2017/2018. Pada uji coba terbatas ini mengambil 12 siswa kelas XI peminatan Matematika dan Ilmu Alam (MIA) yang terdiri dari 4 orang siswa kelompok atas, 4 orang siswa kelompok menengah, daan 4 orang siswa kelompok bawah ditinjau dari kemampuan akademik siswa.

Jenis penelitian ini adalah penelitian dan pengembangan, yaitu meneliti dan mengembangkan media pembelajaran berupa media LKPD berbasis Problem Based Learning untuk melatihkan literasi sains pada materi asam basa kelas XI. Penelitian pengembangan ini, mengacu pada metode Research and Development (R\&D).

Borg \& Gall (1989) menjelaskan bahwa pendekatan Research and Development (R\&D) dalam pendidikan meliputi sepuluh langkah, yaitu: 1) Studi Pendahuluan (Research and Information Collecting); 2) Merencanakan Penelitian (Planning); 3) Pengembangan Desain (Develop Preliminary of Product); 4) Uji coba terbatas (Preliminary Field Testing); 5) Revisi Hasil Uji Lapangan Terbatas (Main Product Revision; 6) Uji coba produk secara luas (Main Field Test); dan 7) Revisi Hasi Uji Lapangan Lebih Luas (Operational Product Revision); 8) Uji Kelayakan (Operational Field 
Testing); 9) Revisi Final Hasil Uji Kelayakan (Final Product Revision) 10) Produk Akhir (Dissemination and Implementation). Penelitian ini terbatas pada langkah ke empat yaitu uji coba tebatas.

Instrumen yang digunakan dalam penelitian ini adalah angket respon dan lembar pre test dan post test. Kepraktisan LKPD yang dikembangkan dilihat dari respon peserta didik. Respon dari peserta didik dapat diketahui dari hasil data angket yang diberikan pada peserta didik. Angket yang telah diisi dihitung berdasarkan kriteria pada Tabel 1 .

Tabel 1.

Pernyataan Skala Guttman

\begin{tabular}{ccc}
\hline Pertanyaan & $\begin{array}{l}\text { Nilai/Skor } \\
\text { pernyataan } \\
\text { positif }\end{array}$ & $\begin{array}{l}\text { Nilai/Skor } \\
\text { pernyataan } \\
\text { negatif }\end{array}$ \\
\hline Ya & 1 & 0 \\
Tidak & 0 & 1 \\
\hline
\end{tabular}

Respon siswa terhadap pembelajaran menggunakan LKPD yang dikembangkan kemudian dihitung dengan rumus:

$$
\begin{aligned}
& \text { prsentase pernyataan positif }(\%) \\
& \qquad=\frac{\text { jumlah jawaban ya }}{\text { jumlah responden }} \times 100 \% \\
& \text { prsentase pernyataan negatif }(\%) \\
& =\frac{\text { jumlah jawaban tidak }}{\text { jumlah responden }} \times 100 \%
\end{aligned}
$$

Berdasarkan hasil analisis angket akan diperoleh kriteria respon siswa dengan kategori sebagaimana disajikan pada Tabel 2.

Tabel 2.

Kriteria Interprestasi Skor Berdasarkan Skala Likert (Dimodifikasi dari Riduwan, 2012).

\begin{tabular}{cl}
\hline Skor rata-rata (\%) & \multicolumn{1}{c}{ Kategori } \\
\hline $0 \%-20 \%$ & Kurang \\
$21 \%-40 \%$ & Cukup \\
$41 \%-60 \%$ & Cukup Baik \\
$61 \%-80 \%$ & Baik \\
$81 \%-100 \%$ & Amat Baik \\
\hline
\end{tabular}

Hasil respon siswa ini dihitung dengan menggunakan rumus respon siswa. Jika persentase siswa yang memberi respon positif $\geq 61 \%$, maka LKPD yang dikembangkan dapat dikatakan baik.

Keefektifan LKPD yang dikembangkan dilihat dari kemampuan literasi sains siswa. Untuk mengetahui kemampuan literasi sains peserta didik dilakukan dengan menganalisis test pre test-post test siswa. Penilaian literasi sains peserta didik dilakukan setelah peserta didik menggunakan LKPD yang dikembangkan.

\section{Hasil dan Pembahasan}

Setelah LKPD yang dikembangkan dinyatakan valid, maka tahap selanjutnya yaitu mengetahui kepraktisan dan keefektifan LKPD yang dikembangkan. Kepraktisan LKPD yang dikembangkan dilihat dari respon peserta didik terhadap LKPD yang dikembangkan. Keefektifan LKPD yang dikembangkan diketahui dari kemampuan literasi sains peserta didik berdasarkan hasil pre test dan post test peserta didik. Untuk mengetahui respon peserta didik dan kemampuan literasi sains peserta didik maka dilakukan uji coba terbatas. Uji coba terbatas dilakukan pada tanggal 12-13 Oktober di SMAN 1 Sidayu. Subjek uji coba terbatas adalah 12 peserta didik yang heterogen dari kelas XII MIA 2. Peserta didik heterogen dilihat dari kemampuan akademiknya yang terdiri atas 4 orang kelompok atas, 4 orang kelompok menengah dan 4 orang kelompok bawah.

Pada penelitian yang telah dilakuakan, peserta didik diberikan pre test untuk mengetahui kemampuan awal literasi sains peserta didik. Kemudian peserta didik diberikan materi asam basa menggunakan LKPD yang dikembangkan. Pada hari pertama peseta didik mendapatkan materi indikator buatan dan pada hari kedua adalah materi indikator alami. Di akhir pertemuan yakni pada hari kedua peserta didik mendapatkan post test untuk mengetahui kemampuan literasi sains peserta didik setelah dilakukan uji coba terbatas menggunakan LKPD yang dikembangkan.

\section{Kepraktisan}

Kepraktisan LKPD yang dikembangkan dilhat dari tanggapan peserta didik. LKPD yang dikembangkan dikatakan praktis apabila ratarata hasil penilaian peserta didik mencapai presentase $\geq 61 \%$. Peserta didik diberikan angket respon yang berisi 15 pertanyaan. Pertanyaan yang diberikan terdapat pertanyaan negatif dan pertanyaan positif. Hal ini untuk menghindari peserta didik yang tidak mengisi angket dengan tidak sungguh-sungguh, Jika pertanyaan dibuat pertanyaan negatif dan positif maka peserta didik akan membaca pertanyan dengan cermat. Berdasarkan hasil respon pada peserta didik didapatkan data pada Gbr 1.

Berdasarkan $\mathrm{Gbr} 1$ presentase terendah pada pertanyaan 4 dan 6 . Pertanyaan 4 adalah apakah LKPD tersebut dapat memotivasi peserta didik untuk belajar dan untuk pertanyaan 6 apakah LKPD yang dikembangkan disertai dengan penjelasan yang sulit dipahami. Hasil angket respon rata-rata adalah $94,99 \%$ dengan kategori amat baik. Berdasarkan hasil tersebut maka, LKPD 
berbasis problem based learning untuk melatihkan kemampuan literasi sains praktis digunakan.

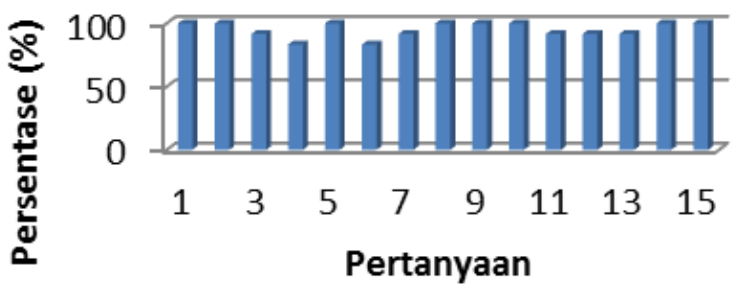

Gbr 1. Hasil Respon Peserta Didik

\section{Keefektifan}

Keefektifan LKPD merupakan ukuran seberapa besar pembelajaran menggunakan LKPD berbasis problem based learning untuk melatihkan kemampuan literasi sains dapat mencapai tujuan pembelajaran. Tujuan pembelajaran yang dimaksud adalah terlatihnya kemampuan literasi sains peserta didik. Untuk mengetahui kemampuan literasi sains peserta didik dilakukan pre test dan post test. Hasil nilai pre test dan post test tersebut kemudian dihitung nilai gain score. Gbr 2 merupakan hasil gain score dari pre test dan post test peserta didik pada uji coba terbatas.

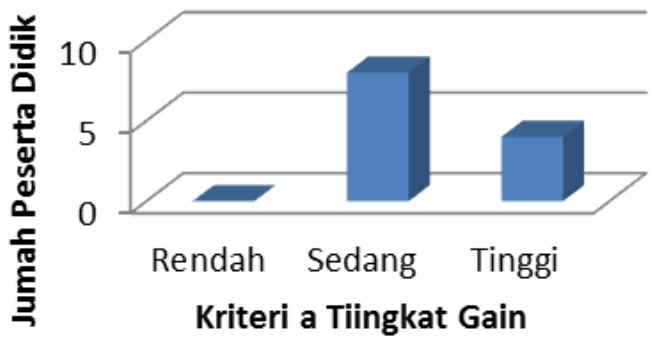

Gbr 2. Hasil Pre Test-Post Test

Gbr 2 menunjukkan 2 peserta didik mendapatkan tingkat gain score sedang dan 8 peserta didik mendapatkan tingkat gain score tinggi. Berdasarkan data tersebut maka kemampuan literasi peserta didik telah terlatih pada peserta didik. Sehingga LKPD berbasis problem based learning untuk melatihkan kemampuan literasi sains praktis digunakan.

\section{Kesimpulan}

LKPD berbasis problem based learning untuk melatihkan kemampuan literasi sains praktis dan efektif untuk digunakan. Kepraktisan LKPD dilihat dari respon peserta didik. LKPD yang dikembangkan mendapatkan tanggapan yang baik sebesar 94,99\% dengan kategori amat baik. Keefektifan LKPD yang dikembangkan dilihat dari gain score dari hasil pre test dan post test peserta didik.

\section{Ucapan terima kasih}

Penulis mengucapkan terimakasih kepada Universitas Negeri Surabaya yang telah membiayai penelitian ini dan kepala sekolah SMAN 1 Sidayu yang telah memberikan izin penelitian di SMAN 1 Sidayu.

\section{Daftar Pustaka}

Anjarsari, P. (2014). Literasi Sains dalam Kurikulum dan Pembelajaran IPA SMP. Prosiding Semnas Pensa VI "Peran Literasi Sains", Surabaya.

Arsyad, A. (2008). Media Pembelajaran. PT. Raja grafindo Persada, Jakarta.

Borg, W.R. \& Gall, M.D. (1989). Educational Research: An Introduction,Fifth Edition. Longman, New York.

BSNP. (2006). Standar Isi untuk Satuan Pendidikan Dasar dan Menengah: Standar Kompetensi dan Kompetensi Dasar SMA/MA. BSNP, Jakarta.

Firman, H. (2007). Analisis Literasi Sains Berdasarkan Hasil PISA Nasional Tahun 2006. Pusat Penilaian Pendidikan Balitbang Depdiknas, Jakarta.

Maturradiyah, N. \& Rusilowati, A. (2015). Analisis Buku Ajar Fisika SMA Kelas XII di Kabupaten Pati Berdasarkan Muatan Literasi Sains. Unnes Physics Educational Journal, hlm 16-20.

Permendikbud No. $81 \mathrm{~A}$ tentang Implementasi Kurikulum 2013.

Keenan, C.W. (1984). Kimia untuk Universitas. Erlangga, Jakarta.

OECD. (2013). PISA 2012 Assassement and Analytical Framework: Mathematics, Reading, Science, Problem Solving and Financial Literacy. Diakses dari http://www.oecd.org pada tanggal 30 Maret 2017.

OECD. (2014). PISA 2012 Results in Focus: What 15-years-olds know and what they can do with what they know. Diakses dari http://www.oecd.org

PISA. (2006). Science Competencies for Tomorrow's World Volume 1-analysis.OECD. [Online]. www.oecd.org/statistics/statlink, diakses 1 April 2017.

Riduwan. (2012). Skala Pengukuran VariabelVariabel Penelitian. Alfabeta, Bandung.

Suyono \& Hariyanto. (2011). Belajar dan Pembelajaran. Remaja Rosdakarya, Bandung.

Toharudin, U., Hendrawati, S. \& Rustaman, A. (2011). Membangun Literasi Sains Peserta Didik. Humaniora, Bandung.

Widjajanti, E. (2008). Kualitas Lembar Kerja Siswa. Makalah Pengabdian Kepada Masyarakat. http://staff.uny.ac.id/system/files/pengabdia $\mathrm{n} /$ endang-widjajanti-Ifx-ms-dr/kualitas-lks.pdf 